\title{
HUMAN RESOURCE MANAGEMENT IN THE FUNCTION OF IMPROVING THE QUALITY OF BANKS' BUSINESS AS A SUPPORT IN FINANCING AGRICULTURE IN SERBIA
}

\author{
Jelena Vemić Đurkovićl, Ivica Nikolić2 , Ivana Marinović Matović ${ }^{3}$ \\ *Corresponding author E-mail: jelena.vemic.djurkovic@educons.edu.rs
}

\begin{abstract}
A R T I C L E I N F O
Original Article

Received: 20 May 2020

Accepted: 05 June 2020

doi:10.5937/ekoPolj2003781V

UDC 331.101.262:[336.71:338. 434(497.11)

\section{Keywords:}

organizational performance, human resource, human resource management, employee satisfaction, banks, financing agriculture

JEL: M500, L250, Q140

A B S T R A C T

The paper presented a multidimensional model of correlation between human resource management practices and the quality of banks' operations as a support in financing agriculture in Serbia, tested twice which gives this analysis a longitudinal character - trend study. Considering that from the firstly surveyed research sample, Agrobank that had showed good results went bankrupt, this in some way brought into question the quality and validity of the tested model of correlation of human resource management practice and performance quality, so there was a need for its re-testing. The indisputable significance of this research is reflected in the fact that, based on the twice-tested multidimensional model of connection between these two entities, it was possible not only to examine how much but also the way in which these human resource management practices generate the quality of banks' operations, as well as the future trends of this practice.
\end{abstract}

(C) 2020 EA. All rights reserved.

\section{Introduction}

The motive for the research within the business banking sector in Serbia lies in the specificity of this sector as an extremely serviceable, which is, by the nature of its activities, highly dependent on the quality of human resources. It is known that creating and maintaining benefits in the service sector depends on succesful relations within the triangle: employees - clients - organizations. From the above it is clear that, in fact,

1 Jelena Vemić Djurković, Ph.D., Associate professor, Educons University, Faculty of Business Economics, 21208 Sremska Kamenica, Vojvode Putnika street no 87, Serbia, Phone: +38164160 8205, E-mail: jelena.vemic.djurkovic@educons.edu.rs, ORCID ID (https://orcid.org/00000002-3379-6530)

2 Ivica Nikolić, Ph.D., Associate professor, Educons University, Faculty of Business Economics, 21208 Sremska Kamenica, Vojvode Putnika street no 87, Serbia, Phone: +381 63521 171, E-mail: profilov@gmail.com, ORCID ID (https://orcid.org/0000-0001-7942-8779)

3 Ivana Marinović Matović, Ph.D., Assistant Professor, Addiko Bank AD, 11070 Novi Beograd, Bulevar Mihajla Pupina street no 6, Serbia, Phone: +381 608634 004, E-mail: ivana.m.matovic@gmail.com, ORCID ID (https://orcid.org/0000-0002-8273-4096) 
the priority task is understanding the impact of the quality of these relations within the triangle on profits and other organizational results of the service organization. The importance of understanding these realtions in the triangle becomes even greater when we consider that agriculture needs constant financial support and contacts with banks which become sensitive and risky because of the need to invest funds in production at once and on a large scale, in accordance with the nature of production, low turnover of funds and low profit generated by agricultural production, which makes impossible to create own sources of financing. (Pejanovic, 2013) The existing and new banking services development for agricultural financing depends first and foremost on the quality of the banking business which is by the extremely serviceable nature dependent on employees and its practice of managing.

Current scientific research has been addressing more and more the problem of identifying indicators of the positive effects of human resource management to the company's performance. The starting point of these research is the belief that today we can not only conclude that human variables constitute the basis of the competitive advantage of the organization, that they are the main source of survival and the driver of growth and development of organizations, but it is very important to answer the question what are the key indicators based on which we can demonstrate and prove the strategic importance of human resources and the human resource management practice for achieving business success (Dusmanescu et al., 2014). Most research that deal with the problem of proving the impact of human resource management practices on business performance have the transversal character. Although they provide data that show the contribution of human resource management practices to organizational performance, they provide very little or insufficient evidence of the modes of that contribution, the level of correlation, and developmental tendencies. In order to better understand and prove the contribution of human resource management to the performance quality, it is necessary to repeat the test on the same or similar sample.

Starting from the above as well the main theoretical stances of relevant authors who were researching the positive effects of human resource management practices to the quality of business operations, the multidimensional model of correlation between human resource management practices and the quality of banks' operations was created and tested twice. The research topic and objectives are based on the necessity of determining the role of human resource management more precisely and defining the directions of its further development with regard to the changes that have occurred in the operations of banks as a support in financing agriculture in Serbia. The purpose of this paper is to analyze and demonstrate the complex connections between the organizational performance of banks and the human resource management practice, accelerate the affirmation of this practice, and point to its strategic importance for the development of banks. 


\section{Theoretical Framework}

„Empirical research investigating the relationship between human resource practices and organizational performance confirm the importance of human resources, their management and their influence on organizational value. However two different approaches exist: first, that there is a "direct" relationship between human resource practices and organizational performance and second stress an "indirect" relationship between human resource practices and organizational performance. In relation to the first research approach, three major perspectives emerge from the existing literature: universalistic, contingency and configuration. In relation to the second research approach, the general consensus developed among researchers is that human resource practices do not lead directly to business performance and it has long been recognized that mechanisms of link between human resource management and organizational performance and intermediate outcomes are central to a more complete understanding of how human resource management drives firm performance“. (Savaneviciene \& Stankeviciute, 2010, p. 428)

"The human resources are often seen as a crucial strategic resource used by companies to achieve this objective. Having in mind that their people are their most valuable asset, companies and their managers need to search for the best ways to manage their employees effectively with an objective to achieve and maintain the desired market position". (Ratković , 2015, pp. 355-356) "The complexity of the relationship between human resource management and organizational performance that involves mediating mechanisms is the most analyzed topic in the field of human resource management known as the black box problem. Many previous researches have explored the link between human resource management and organizational performance and demonstrated positive correlations, but only a few among them have successfully addressed the nature of this connection, how and why human resource management practices impact on performance". (Peregrino de Brito \& Oliveira, 2016) The researchers Savaneviciene and Stankeviciute in their extensive literature review, gave "the comparison of the black box models - (Table 1)". (Savaneviciene \& Stankeviciute, 2010, p. 431)

Table 1. Comparision of the black box models

\begin{tabular}{|c|c|c|c|c|}
\hline Author & HR practices & \begin{tabular}{|l|}
$\begin{array}{l}\text { Mediating } \\
\text { variables }\end{array}$ \\
\end{tabular} & \begin{tabular}{|l|} 
HR-related \\
outcomes
\end{tabular} & \begin{tabular}{|l|}
$\begin{array}{l}\text { More distal } \\
\text { outcomes }\end{array}$ \\
\end{tabular} \\
\hline $\begin{array}{l}\text { Becker et al. } \\
\text { (1997) }\end{array}$ & Not specified & $\begin{array}{l}\text { Employee skills, } \\
\text { Motivation, Job } \\
\text { design, Work } \\
\text { structures }\end{array}$ & $\begin{array}{l}\text { Creativity, } \\
\text { Productivity, } \\
\text { Discretionary effort }\end{array}$ & $\begin{array}{l}\text { Improved } \\
\text { Operating } \\
\text { Performance } \\
\text { Profits and } \\
\text { Growth Market } \\
\text { Value }\end{array}$ \\
\hline
\end{tabular}




\begin{tabular}{|c|c|c|c|c|}
\hline Author & HR practices & \begin{tabular}{|l|}
$\begin{array}{l}\text { Mediating } \\
\text { variables }\end{array}$ \\
\end{tabular} & $\begin{array}{l}\text { HR-related } \\
\text { outcomes }\end{array}$ & \begin{tabular}{|l|}
$\begin{array}{l}\text { More distal } \\
\text { outcomes }\end{array}$ \\
\end{tabular} \\
\hline Guest (1997) & $\begin{array}{l}\text { Selection, Training, } \\
\text { Appraisal, Rewards, Job } \\
\text { design, Involvement, } \\
\text { Status and Security }\end{array}$ & $\begin{array}{l}\text { Employee skills, } \\
\text { Abilities, an } \\
\text { appropriate Role } \\
\text { and understanding } \\
\text { of that Role }\end{array}$ & $\begin{array}{l}\text { Commitment, } \\
\text { Quality, Flexibility } \\
\text { Effort/motivation, } \\
\text { Cooperation, } \\
\text { Involvement, } \\
\text { Organizational } \\
\text { citizenship }\end{array}$ & 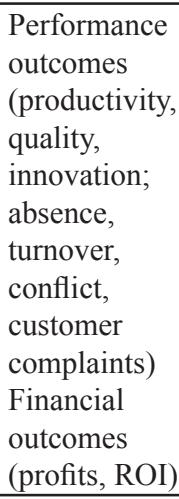 \\
\hline $\begin{array}{l}\text { Purcell et al. } \\
\text { (2003) }\end{array}$ & \begin{tabular}{|l|} 
Job security, Career \\
opportunity, Performance \\
appraisal, Training \\
and Development; \\
Recruitment/Selection, \\
Pay satisfaction, Worklife \\
balance, Job challenge/Job \\
autonomy, Teamworking, \\
Involvement, \\
Communication
\end{tabular} & $\begin{array}{l}\text { AMO framework: } \\
\text { Abilities, } \\
\text { Motivation, } \\
\text { Opportunity to } \\
\text { participate }\end{array}$ & $\begin{array}{l}\text { Organizational } \\
\text { commitment } \\
\text { Motivation Job } \\
\text { satisfaction }\end{array}$ & $\begin{array}{l}\text { Performance } \\
\text { outcomes }\end{array}$ \\
\hline $\begin{array}{l}\text { Wright, } \\
\text { Nishii (2006) }\end{array}$ & $\begin{array}{l}\text { Intended/Actual/Perceived } \\
\text { HR practices }\end{array}$ & Line managers & $\begin{array}{l}\text { Employee reactions } \\
\text { (affective, cognitive, } \\
\text { behaviour) }\end{array}$ & $\begin{array}{l}\text { Organization } \\
\text { performance }\end{array}$ \\
\hline
\end{tabular}

Source: (Savaneviciene \& Stankeviciute, 2010, p. 431)

"Considering the analysis of the comparison of the black box models, primarily the quantity of boxes and the content of each box in the "black box", Savaneviciene and Stankeviciute pointed out the following: 1) although the accurate assessment of human resource management and firm performance link requires reliable and valid assessment of human resource practices, different models comprise various practices. 2) Human resource related outcomes impact more distal performance outcomes: only when human resource related outcomes are achieved it is possible to expect higher performance, 3 ) despite varying models of "black box", the similarity among all is that they all have their basis in a linear causal process. 4) hereby putting too many boxes in the model will not "open the black box", and putting too much items in the boxes will not make the model more insightful and 5) any theoretical or empirical effort should at least specify some mediating variable(s), but not how many“", (Savaneviciene \& Stankeviciute, 2010, pp. 431-432)“

Kalyani and Chong noticed that "the development of knowledge on human resource management has been focusing mainly on traditional manufacturing organisations, with little attention rendered to service-based organisations. A better understanding of how the human resource practices relate to the performance of the banking sector allows 
banks to compete in this competitive environment through appropriate utilisation of the practices“. (Kalyani \& Chong, 2018, p. 16)

Human resource management and organizational performance link analysis is even more complex in financial sector. Masum, Azad and Beh characterized that "the impact of human resource practices on bank performance is too complex to be measured. To rationalize the necessary investments on human resource department, it is the contribution of human resource practice to the organizational performance of banks must be examined. In this study, the authors on a sample of 48 banks in Bangladesh proved that there is an positive impact of human resource practices on the performance of the banks". (Masum, Azad, \& Beh, 2015, p. 382)

Bartel analyzing the relationship between the human resource management environment and establishment performance to the service sector by examining the branch operations of a large Canadian bank highlighted that, with few exceptions, the prior industry studies focus only on the manufacturing sector, despite the fact that most employees work in service-producing industries. The human resource management environment can be an even more important determinant of productivity in the service sector than in the manufacturing sector, given the much larger share of total production costs accounted for by employment, and the much more extensive direct contact between employees and customers, in services". (Bartel, 2004, p. 181) Bartel's research showed "a positive correlation between the employees' satisfaction with human resource management and branch performance measured by annual sales and capital stock". (Bartel, 2004) Gulzar pointed out that "human resource management is very important for banks because banking is a service industry. Human input is the single largest input to the banking industry. The level of efficiency/productivity of this input is reflected in the quality of service offered by the banks to its customers, as also in its ultimate growth, productivity and profitability. The main purpose of his study was designed to explore and compare human resource management practices and their impact on organizational performance in Indian Public Sector Banks. The data were analyzed statistically and finding revealed that human resource management practices have huge impact on the organizational performance in banking sector". (Gulzar, 2018, p. 89)

Ali, Lei and Wei in their research indicate that "given the tough competition in the service industry, it is increasingly significant for the banking sector to understand employee relations climate, and how human resource practices affect performance of the organization and employee relations climate that best fulfill the needs of the organization. The purpose of their study was to examine the mediating effect of employee relations climate between the bundle of strategic human resource management practices and organization performance in Chinese banking sector. The results of this study indicate that the bundle of strategic human resource management has a positive significant relationship with operational performance. Also, employee relations climate mediates the relationship between strategic human resource management and organizational performance". (Ali, Lei, \& Wei, 2018, p. 115) 


\section{Materials and methods}

The afore mentioned approaches and research indicate that human resource management practices influence the knowledge, capabilities, skills and performance of employees who generate business success, and that the link between good human resource management practices and the performance quality is complex, and the analysis requires the introduction of intermediate variables. As two intermediate variables in this study were taken: the value of human resources and the employee satisfaction.

The idea of this research is to take into consideration the following relationships as the ground for designing this multidimensional model for evaluating the human resource management system as the generator of business bank quality in Serbia: firstly, the relationship between the quality of the human resource management system and the quality of the bank performance, respectively the research aim is to show that there is a statistically significant correlation between the quality of the human resource management practice and bank business performance; secondly, the relationship between the quality of the human resources management system and the value of human resources, respectively the research aim is to show that there is a statistically significant correlation between the quality of the human resources management practice and the competitiveness of human resources; thirdly, the relationship between the competitivness of human resources and the quality of bank performance, respectively the research aim is to show that there is a statistically significant correlation between the value of human resources and the quality of the bank performance; fourthly, the relationship between the quality of human resource management system and employee satisfaction, respectively the research aim is to show that there is a statistically significant correlation between the quality of the human resource management practice and the satisfaction of employees with their jobs in the bank; fifthly, the relationship between employee satisfaction and the quality of human resources, respectively the research aim is to show that there is a statistically significant correlation between the value of the human resources and the satisfaction of employees with their jobs in the bank and sixthly, the relationship between employee satisfaction and the quality of performance, respectively the research aim is to show that there is a statistically significant correlation between the satisfaction of employees with their jobs in the bank and bank business performance. The six types of relationships defined in this way determine four research fields: the analysis of organizational performances, the value of human resources management, the competitiveness of human resources, and employee satisfaction, and quantitative and qualitative indicators are defined for each field.

Considering the longitudinal character, the study was carried out twice and represent the trend study. The first survey was conducted in the period January-November 2010 and the sample included human resource departments of twelve banks: Bank Intesa, Erste Bank, Hypo Alpe Adria Bank, Commercial Bank, Opportunity Bank, Čačanska Bank, Volksbank, OTP Bank, KBC Bank, Findomestic bank, Agrobank and Credit Agricole Bank. (Vemić Đurković, Jotić, \& Marić , 2013) Key changes in the banking sector, first 
of all, changes in the ownership structure of the surveyed banks, in the period from 2010 to the end of 2016: Bankrupcy of Agrobank, Volksbank was taken over by the Russian Sberbank, KBC Bank was taken over by Telenor Bank, Čačanska Bank was taken over by Turkish Halkbank, Hypo Alpe Adria Bank changed the owner and became Addiko Bank, and the Direktna Bank from Kragujevac took over Findomestik Bank. Considering that from the firstly surveyed research sample, Agrobank that had showed good results went bankrupt and that other five banks changed the owner and started operating under the different name, this in some way brought into question the quality and validity of the tested model of correlation of human resource management practice and performance quality, so there was a need for its re-testing. The second survey was carried out in the period from January to November in 2016 and the sample included human resource departments of eleven banks: Bank Intesa, Commercial Bank, Credit Agricole Bank, Erste Bank, OTP Bank, Opportunity Bank, Sberbank, Direktna bank, Halkbank, Telenor Bank and Addiko Bank. Considering that the items in the questionnaire required a high level of human resource management knowledge, the survey included human resource managers as part of a research sample, because it was assumed that this group of respondents would provide relevant answers to the questions asked.

In selecting banks for the research sample, in addition to taking into account the sample representativeness according to the criterion of assets balance, total number of employees and market share (at least one-third of banks in the banking sector), special attention was paid to the special requirement of the longitudinal study character to involve those banks that were included in the first survey of this model in order to get as valid data as possible. In both research processes, data were collected through the survey method using the questionnaire instrument. An alpha coefficient was applied for the reliability of the questionnaire. The type of diagnostic measure is the reliability coefficient that estimates the consistency of the whole scale, where the Cronbach Alpha is the most widely used measure. As in the first model tested, the questionnaire consisted of four parts. The first part was about the respondent's characteristics - gender, age, education level and years of service at the bank (Cronbach Alpha subscale .798). The second part was about questions related to the quality of human resource management practices. The quality of the represented human resource management practices of the observed banks in the study was analyzed on the following: competitiveness of the staff in the human resource department of the bank - gender, age, education level, education investment, years of service (Cronbach Alpha subscale .812), quality of organization of the work of the department - division of departments into sectors, outsourcing administrative activities, existence of clear, defined and adopted human resource procedures (Cronbach Alpha subscale .753), the quality of performing generic human resource management activities - planning - analytical processes, recruitment processes, human resource development and maintenance processes, process integration (Cronbach Alpha subscale .932) and evaluation of the importance of human resource management practice strategic approach, financial investment in human resource management activities, formalized system of evaluation of work results (Cronbach Alpha subscale .868). Third 
part was about questions related to the value of human resource which was analyzed on the following: demographic structure of staff - age, gender structure (Cronbach Alpha subscale .768), education of staff - average qualification structure of employees, investments in their education, qualification structure of new employees (Cronbach Alpha subscale .838) and indicators of the mobility of employees - the average length of service, absenteeism and fluctuation rate, number of new employees in the last three years (Cronbach Alpha subscale .898). Fourth part was about questions related to the drivers of human resources, employee satisfaction with the job which was analyzed on the basis of the human resources manager's perceptions and opinions of the analyzed banks about their employees' satisfaction factors. The following satisfaction factors were offered to them: salary, professional development opportunity, job challenge, job security, relationships with executives, interpersonal relationships, reward system and working conditions (Cronbach Alpha subscale .819). It can be stated that the reliability of the subscale in all four parts of the questionnaire is high since it is the lower bound for the Cronbach Alpha is .70. The analysis of the organizational performances of the observed banks was investigated on the basis of financial parameters (market share, ROA, ROE, capital adequacy and liquidity) and non-financial parameters (number of clients, branches, subsidiaries and ATMs, (non)possession of certificates, awards or recognitions for the quality of banking services and regular monitoring of client satisfaction) available in business reports on their websites for both research periods.

The initial idea of this research was to find a way in which the contribution of human resources management practices to the business performance of the observed banks could be analyzed in a multidimensional manner. The method used in this study consisted of suggesting a measure that would represent a (characteristic, average) value which as such looks at several indicators together. These measures used to represent a characteristic, average value of an entity from a sample are called the measures of central tendency. (Hedrih, 2006)

Based on this, as in the first model tested, "banks have been evaluated and the final result of the analysis is their multi-criteria ranking individually for each research field. In order to make an easier conclusion about whether and to what extent their interconnectedness exists, the multi-criteria ranking of banks, based on the use of percentiles and percentile ranks, is given in three groups: banks above average, average banks and banks below average. Repeated research on a similar sample made it possible to compare the ranks obtained from different periods of time, thus providing an opportunity to identify the developmental tendencies of human resource management practices in the banking sector in order to contribute to its quality of performance. Descriptive analysis, rating and ranking of banks by calculating summative scores and using percentiles and percentile ranks gave specific answers to two questions: firstly, which banks according to four defined groups of indicators (organizational performance, human resource management practice, human resource value, and employee satisfaction) are superior and other, what kind of differences are there among them according to the description of the characteristics of these indicators, then the Pearson correlation was used, which 
was intended to show if the indicators used in the descriptive analysis are important for the performance quality, whether there is a correlation among them and what type of correlation it is" (Vemić Đurković, Jotić, \& Marić , 2013, p. 103)

\section{Research results and dicussion}

"Based on the percentile and used percentile ranks, the ratings and ranking were performed according to the financial performance for 2010 of the observed banks in three groups: banks above average (value - above C68 centiles): Bank Intesa, Commercial, Hypo and Erste Bank, average banks (value between C34 and C67 centiles): Agrobank, Volks, Čačanska and Credit Agricole Bank and banks below average (value below C33 cent): KBC, Opportunity, Findomestic and OTP Bank”. (Vemić Đurković, Jotić, \& Marić , 2013, p. 99) For 2016: banks above average (value - above C68 centiles): Bank Intesa, Sberbank. Halkbank and Erste Bank, average banks (value between C34 and C67 centiles): Opportunity Bank, Direktna Bank and Credit Agricole Bank and banks below average (value below C33 centiles): Telenor, Commercial Bank, Addiko Bank and OTP Bank.

"Based on the used percentiles measures and percentile ranks, the surveyed banks were classified according to non-financial performance for 2010: according to three groups: banks above average (value - above C68 centiles): Bank Intesa, Commercial, Hypo and Erste Bank, average banks (value between C34 and C67 centiles): Agrobank, Volks, OTP and Credit Agricole Bank and banks below average (value - below C33 centiles): KBC, Opportunity, Findomestic and Čačanska Bank”. (Vemić Đurković, Jotić, \& Marić , 2013, p. 100) For 2016: banks above average (value - above C68 centiles): Bank Intesa, Sberbank, Opportunity and Erste Bank, average banks (value between C34 and C67 centiles): Halkbank, Direktna bank, Credit Agricole and Commercial Bank and banks below average (value - below C33 centiles): Telenor, Addiko Bank and OTP Bank.

"The analysis of the multi-criteria ranking shows that there are not significant deviations, which means that those banks that have a larger number of clients, branches, employ more workers, enjoy some kind of recognition for the quality of banking services and monitorclient satisfaction with the banking service also have better financial results. By crossing the data, the final multi-criteria ranking and the classification of the observed banks into three groups was obtained for 2010: banks above average (value - above C68 centiles): Bank Intesa, Commercial, Hypo and Erste Bank, average banks (value between C34 and C67 centiles): Agrobank, Volks, OTP and Credit Agricole Bank and banks below average (value below C33 centiles): KBC, Opportunity, Findomestic and Čačanska Bank”. (Vemić Đurković, Jotić, \& Marić , 2013, p. 100) For 2016: bank above average (value - above C68 centiles): Bank Intesa, Sberbank, Opportunity and Erste Bank, average banks (value between C34 and C67 centiles): Halkbank, Credit Agricole and Commercial Bank and banks below average (value - below C33 centiles): Direktna Bank, Telenor, Addiko Bank and OTP Bank. 
Based on the percentile measures and percentile ranks, according to the quality of the represented human resource management practices the observed banks were put into three groups "for 2010: banks above average (value above C68 centiles): Hypo, Erste, Intesa and Commercial Bank, average banks (value between C34 and C67 centiles): Čačanska, Volks, Agrobank and Opportunity Bank and banks below average (value below C33 centiles): Findomestic, KBC, Credit Agricole and OTP Bank”. (Vemić Đurković, Jotić, \& Marić , 2013, p. 101) For 2016: banks above average (above C68): Bank Intesa, Erste, Sberbank and Opportunity Bank, average banks (value between C34 and C67 centiles): Halkbank, Credit Agricole Bank and Commercial Bank and the banks below average (value below C33 centiles): Addiko, Telenor, Direktna and OTP Bank.

The results highlighted the difference in the quality of human resource management among the three groups of the observed banks. Those banks that have a more advanced human resource management have: more quality staff in human resources departments, better organization of their work, better approach to conducting main activities. Comparing the results of a descriptive analysis of the indicators of the development of the main human resource management activities in the surveyed banks from both research periods, it can be concluded that: there has been a significant development of the quality of human resource management activities, in particular the recruitment process, attracting people and developing the employer brand, integrated approach in conducting human resource management practices, there has been a growing appreciation of the importance of human resources management for the quality of performance. It is interesting to point out the fact that in the first survey the activity of education, training and development has been identified as the biggest challenge of this practice, but in the second survey it was the system of rewarding and evaluating work results and behavior, which leads to the conclusion that the bank wants to justify the investments through evaluation and reward and retain experts from this field. Many human resources management processes have been digitalized that have made human resource managers more efficient.

Based on the used percentile and percentile ranks, the rating and ranking according to "the quality of human resources put the observed banks in three groups for 2010: banks above average (value above C68): Hypo, Erste, Bank Intesa and Commercial Bank, average banks (value between C34 and C67 centiles): Čačanska, Volks, Agrobank and Opportunity Bank and banks below the average (value below C33 centiles): Findomestic, KBC, Credit Agricole and OTP Bank". (Vemić Đurković, Jotić, \& Marić , 2013, p. 102) For 2016: banks above average (value above C68 centiles): Bank Intesa, Erste, Sberbank, average banks (value between C34 and C67 centiles): Halkbank, Credit Agricole Bank, Opportunity and Commercial Bank and banks below average (value below C33 centiles): Addiko, Telenor, Direktna and OTP Bank.

Comparing the results of a descriptive analysis of the indicators of the competitiveness of human resources in the surveyed banks from both research periods, it can be concluded that there has been significant investment in the quality of employees, not only their technical competences, but also digital and interpersonal skills. There have 
been significant changes in the quality of the structure of employees in the direction of recruiting skilled workers primarily in the field of information technologies despite the planned reductions. Special programs have been developed for the development and retention of key employees, which leads to a conclusion about the increased awareness of the importance of human resources for business success.

Based on the used percentile measures and percentile ranks, "the rating was done according to the differences in the satisfaction of the employees that put the observed banks in three groups for 2010: banks above average (value above C68 centiles: Hypo, Erste, Bank Intesa and Commercial Bank then average banks (between C34 and C67 centiles): Čačanska, Volks, OTP and Opportunity Bank and banks below the average (value below C33 centiles): Findomestic, KBC, Credit Agricole and Agrobank". (Vemić Đurković, Jotić, \& Marić , 2013, p. 103) For 2016: banks above average (value above C68 centiles): Banca Intesa, Erste, Sberbank, average banks (value between C34 and C67 centiles): Halkbank, Credit Agricole Bank, Opportunity and Komercijalna banka and banks below average (below C33 centiles): Addiko, Telenor, Direktna and OTP Bank.

"The descriptive analysis clearly highlighted the difference in the quality of the human resources driver between the three groups of observed banks for both the research period, for 2010" (Vemić Đurković, Jotić, \& Marić , 2013, p. 103) and for 2016. Respondents in the survey were asked to indicate what the most common sources of satisfaction and discontent among bank employees are. The answers they offered were the following factors of satisfaction: salary, professional development, job challenge, job security, relationships with managers, interpersonal relationships, reward system and working conditions. Comparing the results of a descriptive analysis of the quality indicators of human resource drivers in the surveyed banks from both research periods it can be concluded that: there was a decline in employee satisfaction in the category of banks above the average. Still, full attention is not paid to the balance of private and business life of workers and there is a great tendency of overtime work. Communication and relations with superiors are elements that particularly affect the satisfaction of employees with the work so superiors need to pay close attention to this factor.

Comparing the results of Pearson's correlation analysis "from 2010 and 2016, we can notice the trend of increasing the level of correlation between human resource management practice and the quality of banks' operations in Serbia for all four research fields. The view of Pearson's correlations for 2010 code N1 and for 2016, code N2, difference of correlation for both research period N3, is given in the next table (Table 2)". (Vemić Đurković, Jotić, \& Marić , 2013, p. 105) 
Table 2. Comparing the rsults of Pearson's Correlations for both research periods

\begin{tabular}{|l|l|l|l|}
\hline \multicolumn{1}{|c|}{ Variables } & \multicolumn{1}{|c|}{$\mathbf{2 0 1 0}$} & \multicolumn{1}{|c|}{$\mathbf{2 0 1 6}$} & Difference \\
\cline { 2 - 4 } & $\mathrm{N}-1$ & $\mathrm{~N}-2$ & $\mathrm{~N}-3$ \\
\hline $\begin{array}{l}\text { Quality of HR practice and quality } \\
\text { of business }\end{array}$ & $\begin{array}{l}\mathrm{r}=.749 \mathrm{p} \leq 0,01-\text { high } \\
\text { correlation }\end{array}$ & $\begin{array}{l}\mathrm{r}=.757, \mathrm{p} \leq 0,01-\text { high } \\
\text { correlation }\end{array}$ & $\leq .8$ \\
\hline $\begin{array}{l}\text { Quality of HR practice and } \\
\text { competitiveness of human } \\
\text { resources }\end{array}$ & $\begin{array}{l}\mathrm{r}=.917 \mathrm{p} \leq 0,01-\text { high } \\
\text { correlation }\end{array}$ & $\begin{array}{l}\mathrm{r}=.937 \mathrm{p} \leq 0,01-\text { high } \\
\text { correlation }\end{array}$ & $\leq .20$ \\
\hline $\begin{array}{l}\text { Competitiveness of human } \\
\text { resources and quality of business }\end{array}$ & $\begin{array}{l}\mathrm{r}=.704 \mathrm{p} \leq 0,01-\text { high } \\
\text { correlation }\end{array}$ & $\begin{array}{l}\mathrm{r}=.717, \mathrm{p} \leq 0,01-\text { high } \\
\text { correlation }\end{array}$ & $\leq .13$ \\
\hline $\begin{array}{l}\text { Quality of HR practice and } \\
\text { satisfaction of employees with their } \\
\text { jobs in the bank }\end{array}$ & $\begin{array}{l}\mathrm{r}=.917 \mathrm{p} \leq 0,01-\text { high } \\
\text { correlation }\end{array}$ & $\begin{array}{l}\mathrm{r}=.927 \mathrm{p} \leq 0,01-\text { high } \\
\text { correlation }\end{array}$ & $\leq .10$ \\
\hline $\begin{array}{l}\text { Satisfaction of employees with } \\
\text { their jobs in the bank and quality of } \\
\text { business }\end{array}$ & $\begin{array}{l}\mathrm{r}=.865 \mathrm{p} \leq 0,01-\text { high } \\
\text { correlation }\end{array}$ & $\begin{array}{l}\mathrm{r}=.868 \mathrm{p} \leq 0,01-\text { high } \\
\text { correlation }\end{array}$ & $\leq .3$ \\
\hline $\begin{array}{l}\text { Satisfaction of employees } \\
\text { with their jobs in the bank and } \\
\text { competitiveness of human } \\
\text { resources }\end{array}$ & $\begin{array}{l}\mathrm{r}=.892 \mathrm{p} \leq 0,01-\text { high } \\
\text { correlation }\end{array}$ & $\begin{array}{l}\mathrm{r}=.894 \mathrm{p} \leq 0,01-\text { high } \\
\text { correlation }\end{array}$ & $\leq 2$ \\
\hline
\end{tabular}

Source: (Vemić Đurković, Jotić, \& Marić , 2013, p. 105) and authors' calculations

Pearson's correlations in this paper show that correlations between all indicators are significant, confirming that hypotheses in the study have been proven. It can be stated that those banks with higher quality human resource management practices produce higher value of human resources and have more satisfied employees and as such contribute to higher quality of business, organizational performance (financial and nonfinancial) than those banks with lower quality management practices human resources. High correlation of all investigated variables, tested twice, proves the validity and quality of the multi-dimensional model of the relationship between the human resource management system and the quality of banks' operations in our country. The results of the research shown in the correlation analysis show that the case of Agrobank (the bank that participated in the first survey and showed good results and went bankrupt) does not call into question the validity and quality of this model of correlation between the practice of human resources management and the quality of banks' operations. The existence of a good quality human resource management practice is an important factor for achieving business success, but not the only and sufficient. Management system, leadership, organizational cultures are just some of the important factors that influence organizational performance.

\section{Conclusion}

The purpose of this paper is to analyze and prove the multidimensional model of the contribution of the human resources management system to the quality of banks' operations as the main support in the financing agriculture in Serbia. The basic scientific contribution of this paper is in identifying, proving and presenting human resources and managing them as important factors for achieving organizational performance of 
banks. A better evaluation of the contribution of human resource management activities has the following benefits: detecting deficiencies for which corrective measures can be identified; detecting good practices that need to be further strengthened; enabling the definition of more compatible goals and strategies of this practice with concrete operating conditions of banks; enabling easier demonstration of the contribution of this practice to the chief managers and owners of banks. The strategic future of the bank and further investment in it depends on the human resource management practice and how understandable and clear the importance of this practice for the success of the bank is to its chief managers.

The company may invest in development programs, teamwork, loyalty, good relationships, quality of human resource management activities, but since these investments are not included in the performance indicators of the company, the calculated financial indicators will greatly underestimate the real contribution of this employee management practice.

The key reason for measuring human resource management is to quantify its contribution to organizational success, that is, to demonstrate the link between human resource management and organizational performance, and the importance of this function for fulfilling organizational goals. It refers to determining how human resource practice activities effect on employees, and through them, on the efficiency and effectiveness of the organization, that is, on defining way and intensity in which human resource practice contributes to organizational success.

\section{Conflict of interests}

The authors declare no conflict of interest.

\section{References}

1. Ali, M., Lei, S., \& Wei, X.Y. (2018). The mediating role of the employee relations climate in the relationship between strategic HRM and organizational performance in Chinese banks. Journal of Innovation \& Knowledge, 3(3), 115-122. doi: https:// doi.org/10.1016/j.jik.2016.12.003

2. Agbozo, G. K., Owusu, I. S., Hoedoafia, M. A., \& Atakorah, Y. B. (2017). The effect of work environment on job satisfaction: Evidence from the banking sector in Ghana. Journal of Human Resource Management, 5(1), 12-18. doi: https://doi. org/10.11648/j.jhrm.20170501.12

3. Anusara, J., Rasel, M., Sultana, A., Chanthamith, B., Kabir, M. H., \& Hasan, M. A. (2019). Comparative Study on Human Resource Management Practices in Banking Sector. American Journal of Marketing Research, 5(3).

4. Bartel,A.P. (2004). Human Resource Management and Organizational Performance: Evidence from Retail Banking. ILR Review, 57(2), 181-203. doi: https://doi.org/1 0.1177/001979390405700202 
5. Delaney, J.T., \& Huselid, M.A. (1996). The impact of human resource management practices on perceptions of organizational performance. Academy of Management Journal, 39(4), 949-969. doi: https://doi.org/10.5465/256718

6. Delery, J.E., \& Doty, D.H. (1996). Modes of Theorizing in Strategic Human Resource Management: Tests of Universalistic, Contingency, and Configurational Performance Predictions. Academy of Management Journal, 39(4), 802-835. doi: https://doi.org/10.2307/256713

7. Dusmanescu, D., Andrei, J., \& Subic, J. (2014). Scenario for implementation of renewable energy sources in Romania. Procedia Economics and Finance, 8, 300305. doi: https://doi.org/10.1016/S2212-5671(14)00094-X

8. Eva, T.P. (2018). Recruitment and selection strategies and practices in the private sector commercial banks of Bangladesh: Evidence from human resource practitioners. European Business \& Management, 4(1), 28-38 doi: https:/doi. org/10.11648/j.ebm.20180401.15

9. Farouk, S., Abu Elanain, H.M., Obeidat, S.M., \& Al-Nahyan, M. (2016). HRM practices and organizational performance in the UAE banking sector: The mediating role of organizational innovation. International Journal of Productivity and Performance Management, 65(6), 773-791. doi: https://doi.org/10.1108/ IJPPM-01-2016-0010

10. Fitzenz, J. (1995). How to Measure Human Resources Management. New York:McGraw-Hill ISBN_9780071369985.

11. Fitzenz, J. (2000). The ROI of Human Capital - Measuring the Economic Value of Employee Performance . New York: AMACOM, Retrieved from https:/epdf.pub/ the-roi-of-human-capital-measuring-the-economic-value-of-employee-performanc e671fc09c9cb5d606a0b9baf4fea63e4b72908.html (October 12, 2014).

12. Fey, C.F., Björkman, I., \& Pavlovskaya, A. (2000). The effect of human resource management practices on firm performance in Russia. The International Journal of Human Resource Management, 11(1), 1-18. doi: https:/doi.org/ $0.1080 / 095851900339963$

13. Gulza, R. (2018). A comparative study of human resource management practices and its impact on organizational performance in Indian public sector banks. International Journal of Human Resource Studies, 8(1), 88-102. doi: https:// doi.org/10.5296/ijhrs.v8i1.12048

14. Hedrih, V. (2006). Elektronski web-bazirani sistem za Osnove psihološke statistike. Retrieved from http://www.hm.co.rs/statistika (December 13, 2014).

15. Hossain, S.M., Roy, M.K., \& Das, P.K. (2017). Factors Affecting Employee's Turnover Intention in Banking Sector of Bangladesh: An Empirical Analysis. ASA University Review, 11(2). 
16. Huselid, M.A., Becker, B.E., \& Beatty, R.W. (2005). The Workforce Scorecard Managing Human Capital to Execute Strategy, Retrieved from http://u.camdemy. com/sysdata/doc/0/07a7ealacadf6fe0/pdf.pdf (September 12, 2015).

17. Jayasinghe, C., \& Mendis, M.V.S. (2017). Stress and job performance: a study on banking sector of northern region of Sri Lanka. International Journal of Research Publications, 1(1).

18. Kalyani, M.W., \& Chong, S.C. (2018). SHRM Practices and Firm Performance in the Banking Industry: An Aspirational Research Framework. International Journal of Advances in Scientific Research and Engineering, 11(13), 16-30. doi: https://doi. org/10.31695/IJASRE.2018.32971

19. Madanat, H.G., \& Khasawneh, A.S. (2018). Level of effectiveness of human resource management practices and its impact on employes' satisfaction in the banking sector of Jordan. Journal of Organizational Culture, Communications and Conflict, 22(1), 1-19.

20. Mansour, N., Gara, E., \& Gaha, C. (2014). Getting inside the black box. Personnel Review, 43(4), 490-514. doi: https://doi.org/10.1108/pr-03-2013-0052

21. Masum, A.K.M., Azad, M.A.K., \& Beh, L.S. (2016). The role of human resource management practices in bank performance. Total Quality Management \& Business Excellence, 27(3-4), 382-397. doi: https://doi.org/10.1080/14783363.2014.1002762

22. Mehta, E. (2016). Literature review on HR practice in banking sector. International research journal of engineering, IT \& scientific research, 2(7), 115-124.

23. Mittal, S., Gupta, V., \& Motiani, M. (2016). Relation between human resource development climate and organisational commitment: empirical study in Indian banking sector. International Journal of Indian Culture and Business Management, 12(2), 204-223. doi: https://doi.org/10.1504/IJICBM.2016.074481

24. Pejanović, R. (2013). Experiments in agrarian and rural economy, Monograph, Faculty of Agriculture, Novi Sad.

25. Peregrino, D.B., \& Barbosa, R.O.L. (2016). The Relationship Between Human Resource Management and Organizational Performance. Brazilian Business Review, 13(3), 90-110. doi: https://doi.org/10.15728/bbr.2016.13.3.5

26. Pološki, V.N. (2004). Human Resource Management in large Croatian companies. Economic Review, 55(5-6), 455-478.

27. Purcell, J. (1999). Best practive and best fit. Human Resource Management Journal, 9(3), 26-41. doi: https://doi.org/10.1111/j.1748-8583.1999.tb00201.x

28. Radjenovic, Z., \& Boskov, T. (2017). Human Capital and Its Impact on the Career Success: Serbian and Macedonian Banking Sector. International Journal of Information, Business and Management, 9(1), 94-107.

29. Ratković, T. (2015). HRM in foreign-owned agricultural and food processing companies in Serbia. Economics of Agriculture, 62(2), 353-367. doi: https://doi. org/10.5937/ekoPolj1502353R 
30. Savaneviciene, A., \& Stankeviciute, Z. (2010) The Models Exploring the "Black Box" between HRM and Organizational Performance, Inzinerine EkonomikaEngineering Economics, 21(4), 426-434.

31. Sikavica, P., \& Bahijerević - Šiber, F. (2004): Management: Management theory and large empirical research in Croatia, Zagreb, Masmedia.

32. Vemić-Đurković, J., Jotić, J., \& Marić, R. (2013). A Comperative Analysis of Contribution of Human Resource Management to Organizational Performance of Banks in Serbia. Industry, 41(4), 91-107. doi: https://doi.org/10.5937/ industrija41-4487

33. Zubović, J. (2010). Development of an economy based on investments in human resources and foreign investments. Belgrade: Institute of Economics.ISBN 978-8680315-83-6. 